\begin{tabular}{|l|l|}
\hline \multicolumn{1}{|c|}{$\begin{array}{c}\text { 2. To: (Receiving organization) } \\
\text { Distribution }\end{array}$} & $\begin{array}{l}\text { 3. From: (originating organization) } \\
\text { Technical Basis and Planning }\end{array}$ \\
\hline $\begin{array}{l}\text { 5. Proj./Prog./Dept./Div.: } \\
\text { Tank 241-SY-101/Waste } \\
\text { Management/TB\&P/Process } \\
\text { Engineering }\end{array}$ & $\begin{array}{l}\text { 6. Design Authority/ Design Agent/cog. } \\
\text { Engr.: } \\
\text { Ruth D. Schreiber }\end{array}$ \\
\hline $\begin{array}{l}\text { 8. originator Remarks: } \\
\text { This document is being released into the supporting document } \\
\text { system for retrievability purposes. }\end{array}$
\end{tabular}

2. To: (Receiving organization)

5. Proj./Prog./Dept./Div.:

Tank 241-SY-101/Waste

Management/TB\&P/Process

engineering

This document is being released into the supporting document system for retrievability purposes.

11. Receiver Remarks: 11A. Design Baseline Document? [] Yes [X] No For release.
4. Related EDT No.:

N/A

7. Purchase Order No.:

$N / A$
9. Equip./Component No.:

$\mathrm{N} / \mathrm{A}$

10. System/Bldg./Facil ity: 241-SY-101

12. Major Assm. Dwg. No.:

N/A

13. Permit/Permit Application No.: N/A

14. Required Response Date: $10 / 08 / 98$

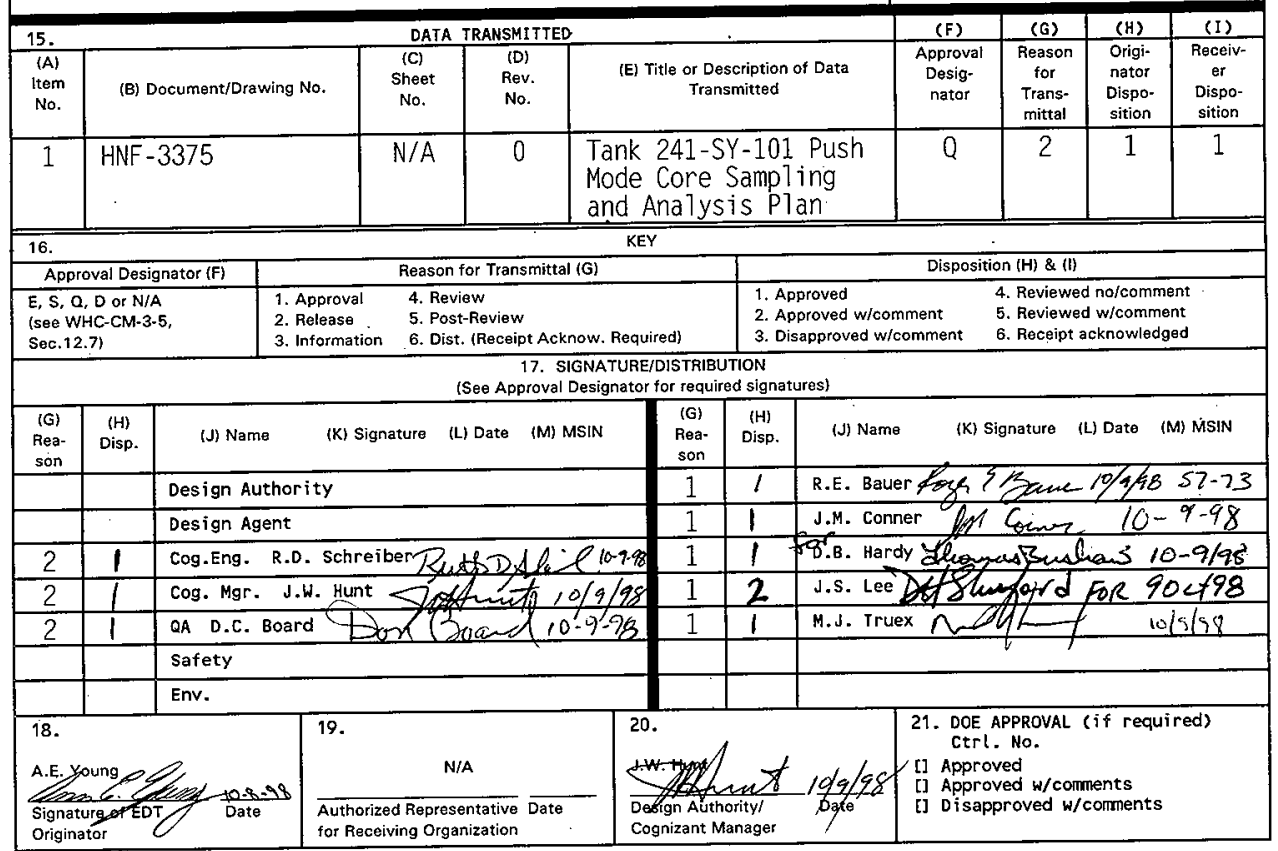




\section{Tank 241-SY-101 Push Mode Core Sampling and Analysis Plan}

John M. Conner

Lockheed Martin Hanford, Corp., Richland, WA 99352

U.S. Department of Energy Contract DE-AC06-96RL13200

EDT/ECN: EDT-622483 UC: 2070

Org Code: 7AB10 Charge Code: CACN 102264/COA EI00

B\&R Code: EW 3120074 Tota1 Pages: 33 cw 10-9-98

Key Words: Tank 241-SY-101, 241-SY-101, SY-101, SY Farm, Push Mode, Push. Sampling. Analysis. Plan

Abstract: N/A

TRADEMARK DISCLAIMER. Reference herein to any specific comercial product, process, or service by trade name, trademark, manufacturer, or otherwise, does not necessarily constitute or imply its endorsement, recommendation, or favoring by the United states Government or any agency thereof or its contractors or subcontractors.

Printed in the United States of America. To obtain copies of this document, contact: Document Control Services, P.0. Box 950, Mailstop H6-08, Richland WA 99352, Phone (509) 372-2420; Fax (509) 376-4989.

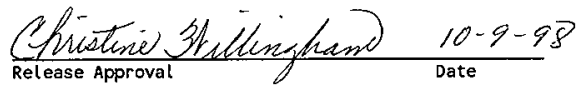

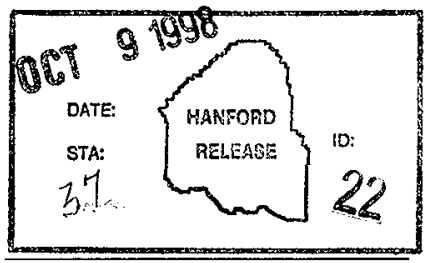

Release Stamp 
HNF-3375

Revision 0

\section{Tank 241-SY-101 \\ Push Mode Core \\ Sampling and Analysis Plan}

J. M. Conner

Lockheed Martin Hanford Corporation

Prepared for the U.S. Department of Energy

Office of Environmental Restoration

and Waste Management 


\section{TABLE OF CONTENTS}

1.0 SAMPLING AND ANALYSIS OBJECTIVES $\ldots \ldots \ldots \ldots \ldots \ldots$

2.0 SAMPLING EVENT REQUIREMENTS $\ldots \ldots \ldots \ldots \ldots \ldots \ldots \ldots \ldots$

2.1 GENERAL REQUIREMENTS $\ldots \ldots \ldots \ldots \ldots \ldots \ldots \ldots \ldots$

2.2 RGS SAMPLING REQUIREMENTS $\ldots \ldots \ldots \ldots \ldots \ldots \ldots \ldots \ldots$

3.0 LABORATORY ANALYSIS REQUIREMENTS $\ldots \ldots \ldots \ldots \ldots \ldots \ldots$

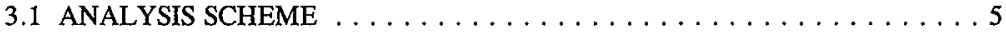

3.1.1 Universal Samples and RGS Samples Selected for Extrusion in Hot Cell

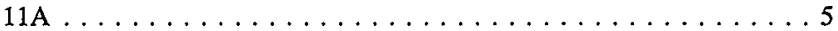

3.1.2 RGS Samples for Retained Gas Analysis . . . . . . . . . 13

3.2 SPECIFIC METHODS AND ANALYSES $\ldots \ldots \ldots \ldots \ldots \ldots \ldots \ldots$

3.2.1 Condensed Phase Sample Analysis . . . . . . . . . . . 13

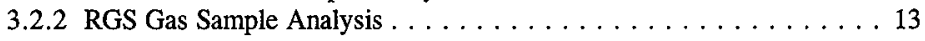

3.2 .3 Solids Solubility Screening . . . . . . . . . . . . 14

3.3 INSUFFICIENT SEGMENT RECOVERY $\ldots \ldots \ldots \ldots \ldots \ldots \ldots \ldots$

4.0 QUALITY ASSURANCE AND QUALITY CONTROL $\ldots \ldots \ldots \ldots \ldots \ldots \ldots$

4.1 SAMPLE COLLECTION $\ldots \ldots \ldots \ldots \ldots \ldots \ldots \ldots \ldots \ldots$

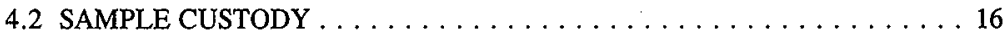

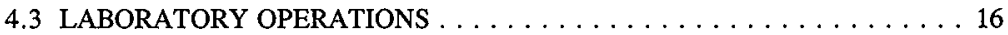

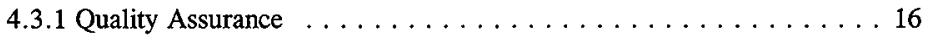

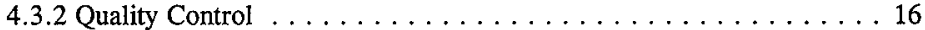

4.3.3 Specific RGS Gas Analytical Requirements .... . . . . . 20

5.0 EXCEPTIONS, CLARIFICATIONS, AND ASSUMPTIONS $\ldots \ldots \ldots \ldots \ldots 22$

5.1 EXCEPTIONS TO DQO REQUIREMENTS $\ldots \ldots \ldots \ldots \ldots \ldots \ldots 22$

5.2 CLARIFICATIONS AND ASSUMPTIONS $\ldots \ldots \ldots \ldots \ldots \ldots \ldots$

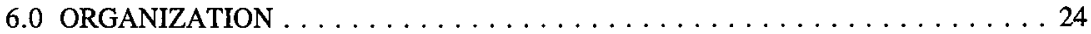

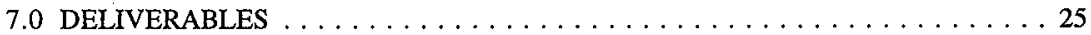

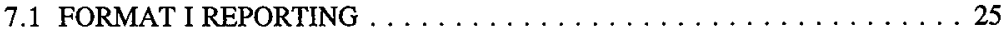

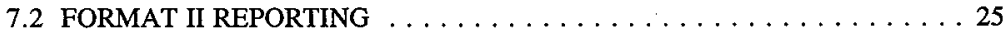

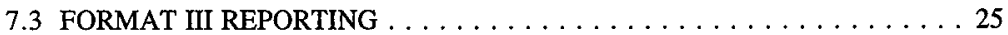

7.4 FORMAT IV REPORTING $\ldots \ldots \ldots \ldots \ldots \ldots \ldots \ldots \ldots \ldots \ldots$

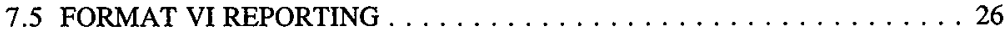

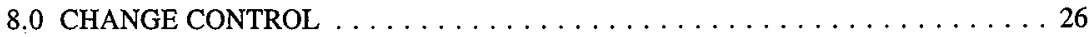

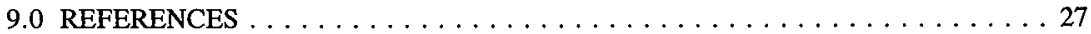




\section{LIST OF TABLES}

1. Tank SY-101 Chemical, Radiological, and Physical Analytical Requirements: Solids . . 6

2. Tank SY-101 Chemical, Radiological, and Physical Analytical Requirements: Liquids . 8

3. Tank SY-101 Analytical Requirements for LAW Privatization: Solids . . . . . . . . . . 10

4. Tank SY-101 Analytical Requirements for LAW Privatization: Liquids . . . . . . . . 11

5. Tank SY-101 RGS Analytical Requirements: Gas . . . . . . . . . . . . . . . . . 14

6. QC Precision and Accuracy Requirements for Condensed Phase Analyses . . . . . . 18

7. Tank SY-101 Project Key Personnel . . . . . . . . . . . . . . . . . . . . 24

\section{LIST OF ABBREVIATIONS}

$\begin{array}{ll}\text { Ci } & \text { curie } \\ \text { CPO } & \text { Characterization Project Operations } \\ \text { DQO } & \text { data quality objective } \\ \text { DSC } & \text { differential scanning calorimetry } \\ \text { g } & \text { gram } \\ \text { g/L } & \text { gram per liter } \\ \text { IC } & \text { ion chromatography } \\ \text { ICP/AES } & \text { inductively coupled plasma - atomic emission spectroscopy } \\ \text { kgal } & \text { kilogallon } \\ \text { kL } & \text { kiloliter } \\ \text { L } & \text { liter } \\ \text { LFL } & \text { lower flammability limit } \\ \text { LiBr } & \text { lithium bromide } \\ \text { LMHC } & \text { Lockheed Martin Hanford Corporation } \\ \text { NCPLX } & \text { non-complexed waste } \\ \text { mL } & \text { milliliter } \\ \text { PHMC } & \text { Project Hanford Management Contract } \\ \text { PIC } & \text { person in charge } \\ \text { PRSST } & \text { propagating reactive system screening tool } \\ \text { QA } & \text { quality assurance } \\ \text { QC } & \text { quality control } \\ \text { RGS } & \text { retained gas sampler } \\ \text { RSST } & \text { reactive system screening tool - adiabatic calorimetry } \\ \text { SY-101 } & \text { 241-SY-101 } \\ \text { SAP } & \text { sampling and analysis plan } \\ \text { TGA } & \text { thermogravimetric analysis } \\ \text { TOC } & \text { total organic carbon } \\ \text { TWRS } & \text { Tank Waste Remediation System } \\ \text { WMH } & \text { Waste Management Hanford } \\ \mu \text { Ci } & \text { microcurie } \\ \mu \text { Ci/g } & \text { microcuries per gram } \\ & \end{array}$


HNF-3375, Rev. 0

\subsection{SAMPLING AND ANALYSIS OBJECTIVES}

This sampling and analysis plan (SAP) identifies characterization objectives pertaining to sample collection, laboratory analytical evaluation, and reporting requirements for push mode core samples from tank 241-SY-101 (SY-101). It is written in accordance with Data Quality Objective to Support Resolution of the Flammable Gas Safety Issue (Bauer 1998), Low Activity Waste Feed Data Quality Objectives (Wiemers and Miller 1997 and DOE 1998), Data Quality Objectives for TWRS Privatization Phase I: Confirm Tank T is an Appropriate Feed Source for Low-Activity Waste Feed Batch X (Certa 1998), and the Tank Safety Screening Data Quality Objective (Dukelow et al. 1995). The Tank Characterization Technical Sampling Basis document (Brown et al. 1998) indicates that these issues apply to tank SY-101 for this sampling event. Brown et al. also identifies high-level waste, regulatory, pretreatment and disposal issues as applicable issues for this tank. However, these issues will not be addressed via this sampling event.

Core sampling of tank SY-101 is planned to address the level growth issue in this tank (Cash 1998a). Retained gas samples will be taken to determine the quantity and composition of gas in the waste. Samples will also be analyzed for chemical and physical properties, and sample material will be used for testing waste behavior such as gas generation. No waste samples have been taken from the tank since the mixer pump was installed in 1993. In addition to the DQOs listed above, Mulkey and Miller (1997) will be used to address compatibility issues associated with the potential transfer of waste from the tank.

\subsection{SAMPLING EVENT REQUIREMENTS}

As of June 30,1998 , tank SY-101 contained $4,323 \mathrm{~kL}(1,142 \mathrm{kgal})$ of waste, consisting of $4,308 \mathrm{~kL}(1,191 \mathrm{kgal})$ of supernatant and $155 \mathrm{~kL}$ (41 kgal) of sludge (Hanlon 1998). This waste volume is equivalent to 1,054 centimeters ( 415 inches) of waste as measured from the bottom centerline of the tank.

The physical profile of the waste can be estimated from data provided in Conner and Koreski (1998). The waste is expected to consist of a crust layer approximately $1.5 \mathrm{~m}$ (59 in) thick, a convective slurry layer of approximately $9 \mathrm{~m}$ (340 in), and an undisturbed solids layer of less than $40 \mathrm{~cm}(16 \mathrm{in})$. The waste is mixed several times a week by a mixer pump, and the distribution of solids in the convective slurry varies with time.

\subsection{GENERAL REQUIREMENTS}

Tank SY-101 will be core sampled using a push mode core sampling truck. Three core samples, consisting of 22 segments each, are expected to be taken from risers 021,022 , and 006 (formerly known as risers $22 \mathrm{~A}, 23 \mathrm{~A}$ and $4 \mathrm{~A}$ ). The sampling objective is to obtain full vertical profiles of the waste; therefore, more or fewer segments may need to be taken depending on the accuracy of the current waste volume records. Retained gas samplers (RGS) will be used for riser 021 , segments $1,2,3,4,10,16$, and 22, and for riser 022, segments 1 , $2,3,4,7,13$, and 21 . Universal samplers will be used for all other samples. All RGS 
samples must be full-segment samples. If partial segments need to be taken, they should be taken for non-RGS segments in the convective layer, approximately segments 10 through 16 .

If quality-affecting changes to the sampling requirements must be made (including the risers, sampling truck, or RGS segments), the change must be recorded and approved by the cognizant engineer, tank coordinator, and RGS point of contact before sampling. This information must be recorded in the work packages (WS-98-00086 for riser 021, WS-9800087 for riser 022 , and WS-98-00172 for riser 006). These work packages will contain the operating procedures and the chain-of-custody records for this sampling event.

One field blank for tank SY-101 shall be obtained in accordance with procedure TO-060-003. The Characterization Project Operations (CPO) person in charge (PIC) or the PIC designate will verify that the field blank is properly created and shipped. For sampling events having multiple PICs, CPO shall determine which PIC will be responsible for the field blank. This field blank is to accompany the samples to the laboratory. All collected samples shall be shipped to the laboratory following the Load/Transport Sample Cask(s) procedure (TO-080-090).

If drill string monitoring instruments indicate a flammable gas level greater than $25 \%$ of the lower flammability limit (Cash 1998b), a vapor grab sample shall be taken from the drill string and sent to M. W. Goheen of Pacific Northwest National Laboratory for analysis. One sample is to be taken at each elevation that the $25 \%$ level is exceeded. Accurate records must be kept of any drill string gas purge operations, including information on the time and duration of the purge and gases used.

The following steps are specified to ensure sampling needs are met:

- Tank farm personnel shall indicate on the chain-of-custody form whether a cask contains an RGS sampler or a universal sampler.

- Tank farm personnel should make a verbal notification to the 222-S Laboratory (373-2435) at least 24 hours in advance of the expected shipment.

- Casks containing the RGS samplers should be transported to the 222-S Laboratory within 24 hours from the time each segment is removed from the tank.

- Casks containing the universal samplers should be transported to the 222-S Laboratory within three calendar days from the time each segment is removed from the tank.

- The 222-S laboratory sample custodian will receive the casks and tag the RGS samplers.

If lithium bromide ( $\mathrm{LiBr}$ ) solution is used in the collection of the core samples, it should be a $0.3 \pm 0.01$ molar solution with a pH greater than 8 . Characterization Project Operations must state the batch number and amount of fluid added at each segment. This information should be indicated on the chain-of-custody form that accompanies the sample to the laboratory. A sample of the $\mathrm{LiBr}$ solution must be provided to the laboratory. This sample shall consist of a 
container filled with $\mathrm{LiBr}$ solution from the same batch of $\mathrm{LiBr}$ solution used during the sampling. This solution shall be analyzed for lithium and bromide in order to determine the concentration of the tracer at the time the sample was taken. If analysis of the waste samples indicates contamination by the $\mathrm{LiBr}$ solution, these data will be used to determine the amount of contamination. If more than one batch of $\mathrm{LiBr}$ solution is used during the sampling event, one solution sample must be provided for each batch.

\subsection{RGS SAMPLING REQUIREMENTS}

These RGS sampler handling requirements are taken from the Sampling Plan for Tank 241-SY101 Retained Gas Sampler Deployment (Bates 1998).

The potential for air entrainment into the RGS sample has been established by recent tests (White 1996). A maximum of approximately $6 \mathrm{cc}$ of air can be entrained into the RGS sample with the current design. In an effort to prevent sample contamination by such entrained air, sampler leading ends are now helium backfilled (procedures detailed in the sampler fabrication/assembly traveler) and the sampler is shipped to the field in a helium-filled, sealed shipping container. The sampler containers shall be maintained in a horizontal orientation until the samplers are unloaded and readied for placement in the drill string. Also, the heliumbackfilled samplers and their associated shipping/storage containers should be kept outside the tank farm radiation area so that the containers can be recycled for use on subsequent samplers. To minimize the chnace of air entrainment in the sample, the sampler is to be removed from the backfill container as near to the time of insertion in the drill string as practical.

The recommended sampling points for RGS are segments $1,2,3,4,10,16$, and 22 in riser 021 and $1,2,3,4,7,13$, and 21 in riser 022 . RGS samples must be full length samples. The RGS sampler unit serial number will be noted in the operations log per procedure NDT-RT401 at the time the sampler unit is loaded into the drill string. The serial number will be cross-referenceable to the tank elevation being sampled with the particular sampler.

On retrieval after filling, the sampler will be scanned with an $\mathrm{x}$-ray scanner system to ensure that the sampler has achieved at least $75 \%$ of the target recovery volume. A video recording of the radiographs will be sent to PNNL for analysis of the waste form and retained gas structure. The radiographs are expected to provide insight into expected void fractions, density, and structure of the waste and greatly augment the post-sampling analysis performed at PNNL. To obtain the necessary information regarding phase distribution, it is required that the following procedure for $\mathrm{x}$-ray be followed:

1) Record calibration images (minimal calibration images include a sampler containing air and water) at the same recording conditions as used for the real waste, i.e., same intensity $(\mathrm{kV})$ and operating frequency. Calibration images should be collected immediately prior to and immediately after each RGS sampler imaging effort in order that the best quantitative information is available for these images. 
2) Record the sampler at $1 \mathrm{X}$ magnification and append the position and $\mathrm{kV}$ information to each image recorded without changing the setting on the $x$-ray power supply (i.e., intensity and frequency) or the recording/imaging equipment.

3) Record at least one image at a $2 X$ magnification of the positions where voids were observed. Append position information if possible.

X-ray imaging records of sample segments immediately adjacent to RGS samples would be of considerable assistance in interpreting and trending of the $\mathrm{X}$-ray derived observations (such as density, void sizes and shapes, and void distributions). X-ray imaging of all core segments is highly recommended. Video recordings of the radiographs of these adjacent sample segments should also be provided to PNNL for analysis.

A second $\mathrm{x}$-ray scan of each segment is highly desirable. The second scan should be at a different angle, ideally $90^{\circ}$ from the first scan.

It is also of interest to determine whether any gas is released from the waste during sampling. For this purpose, in-tank video capability should be used to record the sampling process through the crust (segments 1 through 4) for each core, and a copy of this video record be provided to PNNL.

For the RGS samples to be as representative as possible, the time between sample retrieval and subsequent analysis must be minimized. When an RGS sample is retrieved from the pushmode sample string, it should be loaded into the transport cask (special flammable gas shipping cask) and moved to the 222-S Building using OTC Transportation Shipping Procedure TO-080-090 and delivered to door 10, where the sample custodian will assume possession of the cask per laboratory procedure LO-090-101. Priority handling is recommended to protect the sampler/cask from extreme temperatures (direct sunlight) prior to shipping. The cask should be moved to an environmentally controlled location as soon as practical.

For this project, not all of the RGS samplers will be extruded in the RGS extruder for gas capture and analysis. Some of the RGS samples will be extruded in the 11A hot cell along with the universal samplers. The tank coordinator will direct the laboratory on which samples to extrude in the different extruders. It is expected that several RGS samplers will be extruded in the RGS extruder before the decision is made on the remaining RGS samplers. If several of the crust samples are successfully processed in the RGS extruder, then the remaining crust samples may be extruded in the 11A universal extruder to permit visual observation and physical and chemical property testing.

\subsection{LABORATORY ANALYSIS REQUIREMENTS}

The extrusion, subsampling, compositing, and analysis requirements are described below. For core samples from tank SY-101, the shipping container must be vented every 27 days to release any accumulated gas. 


\subsection{ANALYSIS SCHEME}

\subsubsection{Universal Samples and RGS Samples Selected for Extrusion in Hot Cell 11A}

In order to comply with Dukelow et al. (1995), Wiemers and Miller (1997), DOE (1998), Certa (1998), Jo (1998), Bauer (1998), Cash (1998b), Mulkey and Miller (1997), and Bates (1998) the following steps shall be performed on each sample:

- Extrude segments, videotaping the extrusion and photographing the extruded segments. The extrusion procedure is LO-160-103 at the 222-S Laboratory.

- Subsample unhomogenized material for physical property testing as directed by the tank coordinator. Subsamples being sent to PNNL should be subsampled directly into $125 \mathrm{~mL}$ jars.

- Subsample crust segments for density measurements as directed by the tank coordinator. Crust density is expected to be measured on half-segments.

- Subsample segment solids and homogenize.

- Settle drainable liquids for at least 16 hours. Note if any floating layer is present (solid or organic). Decant the liquid and recombine settled solids with segment solids and homogenize.

- Analyze segment solids and liquids as shown in Tables 1 and 2.

Note: Samples from the third core (riser 006) should not be analyzed according to Tables $I$ and 2 unless directed by the tank coordinator.

- Prepare stratum composites for each core as directed by the tank coordinator. Analyze composites as shown in Tables 1 and 2.

- Prepare tank liquid and solids composite in accordance with Wiemers and Miller (1997) and as directed by the tank coordinator. Analyze for LAW privatization according to Tables 3 and 4 . Each composite must be analyzed three times.

- Provide sample for testing to resolve flammable gas and crust growth issues as directed by the tank coordinator. Tests not called out in this SAP will be controlled by a letter of instruction or a test plan.

- Provide composite material for solids solubility screening (Wiemers and Miller 1997). The solids solubility screening is discussed in Section 3.2.3.

- Make a whole tank composite of at least $2 \mathrm{~kg}$ and provide to D. L. Herting for process testing (Jo 1998).

If liner liquid is observed during extrusion and the liquid is in sufficient quantity to collect, the liner liquid may be retained and analyzed at the discretion of the tank coordinator. In this event, this addition of analyses will not require a revision to this SAP.

Any decisions, observations, or deviations made to this work plan, or during the sample breakdown and analyses shall be documented in writing with justification. These decisions and observations shall be reported in the data report. The reporting formats for analyses are contained in Tables 1 through 4 and are described in Section 7.0. 


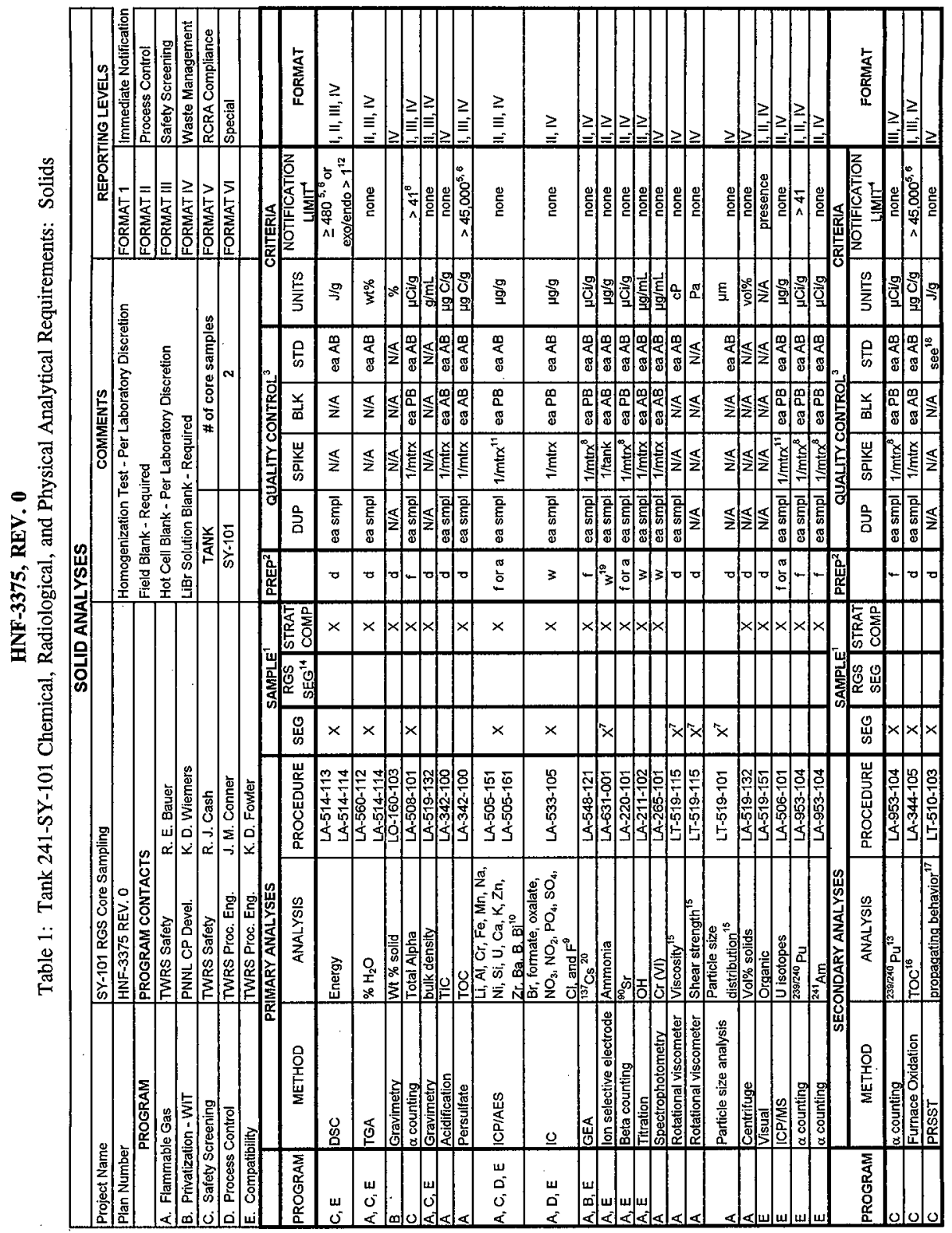




\section{HNF-3375, REV. O}

Table 1: Tank 241-SY-101 Chemical, Radiological, and Physical Analytical Requirements: Solids

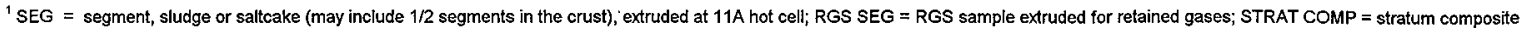
${ }^{2} \mathrm{~d}=$ direct, $\mathrm{f}=$ fusion, $\mathrm{a}=$ acid, $w=$ water

${ }^{3} \mathrm{DUP}=$ duplicate, $\mathrm{BLK}=$ blank; STD = calibration standard, ea $=$ each, smpl = sample, $\mathrm{AB}=$ analytical batch, $\mathrm{PB}=$ preparation blank, $\mathrm{mtrx}=$ matrix, $\mathrm{N} / \mathrm{A}=$ not applicable

"Units for notification limits and expected range are those listed in the "units" column.

${ }^{5}$ Dry weight basis

These analytes are to be compared to the limit by calculating the one-sided, upper $95 \%$ confidence limit for the sample result (to be performed by Process Engineering).

${ }^{7}$ These analyses will only be performed on specified subsamples

${ }^{2}$ Tracer or carrier may be used in place of a spike and results corrected for recovery.

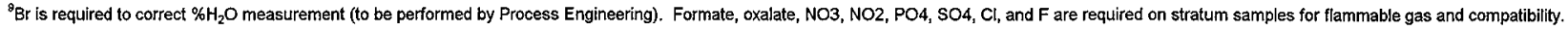
Results should be reported for all IC analytes, however, the QC reqmis of Table 6 apply only to those listed.

${ }^{10} \mathrm{Li}$ is required to correct $\% \mathrm{H}_{2} \mathrm{O}$ measurement (to be performed by Process Engineering). $\mathrm{Al}, \mathrm{Cr}, \mathrm{Fe}, \mathrm{Mn}, \mathrm{Na}, \mathrm{Ni}$, $\mathrm{Si}$, and $\mathrm{U}$ are required as secondary safety screening analytes; required if total alpha exceeds notification limits. $\mathrm{Na}, \mathrm{Al}, \mathrm{Cr}, \mathrm{Ca}, \mathrm{Fe}, \mathrm{K}, \mathrm{Ni}, \mathrm{Zn}, \mathrm{Zr}, \mathrm{Ba}, \mathrm{Si}, \mathrm{B}$, and $\mathrm{Bi}$ are flammable gas analytes and apply only to samples chosen to represent strata.

$\mathrm{Al}_{1} \mathrm{Cr}_{1} \mathrm{P}, \mathrm{Na}, \mathrm{S}$, and $\mathrm{Si}$ are of interest to Privatization-WIT. Results should be reported for all ICP/AES analytes, however, the $\mathrm{QC}$ requirements of Table 4 apply only to those identified here.

${ }^{11}$ Either serial dilutions or matrix spikes will be performed.

${ }^{12}$ Applies only to the stratum composite. If exotherm is observed, both the endotherm and exotherm values must be reported.

${ }^{13}$ Performed if total alpha exceeds notification limits.

${ }^{14}$ Analyses to be conducted on the RGS segments will be at the direction of the tank coordinator.

${ }^{15}$ These analyses may be conducted at PNNL or another laboratory. Unhomogenized samples are to be used for viscosity and shear strength.

${ }^{18}$ Furnace oxidation TOC is to be run on those samples which exhibit exotherms, but have persulfate TOC values that account for $<75 \%$ of the exotherm energy (see Equation 4).

${ }^{17}$ PRSST may be run on the sample exhibiting the highest DSC or TOC result. Contact the tank coordinator before proceeding with this analysis.

${ }^{18}$ Calibrations of heater resistance, time, temperature, pressure, containment volume, and sample weight will be performed to measure accuracy as described in procedure LT-510-103.

${ }^{12}$ The water digestion for ammonia should be performed at room temperature to avoid excessive volatilization. Handling should be minimized prior to ammonia analysis

${ }^{20}$ Results should be reported for all GEA analytes, however the QC requirements of Table 6 apply only to those analytes listed. 
HNF-3375, REV. 0

Table 2: Tank 241-SY-101 Chemical, Radiological, and Physical Analytical Requirements: Liquids

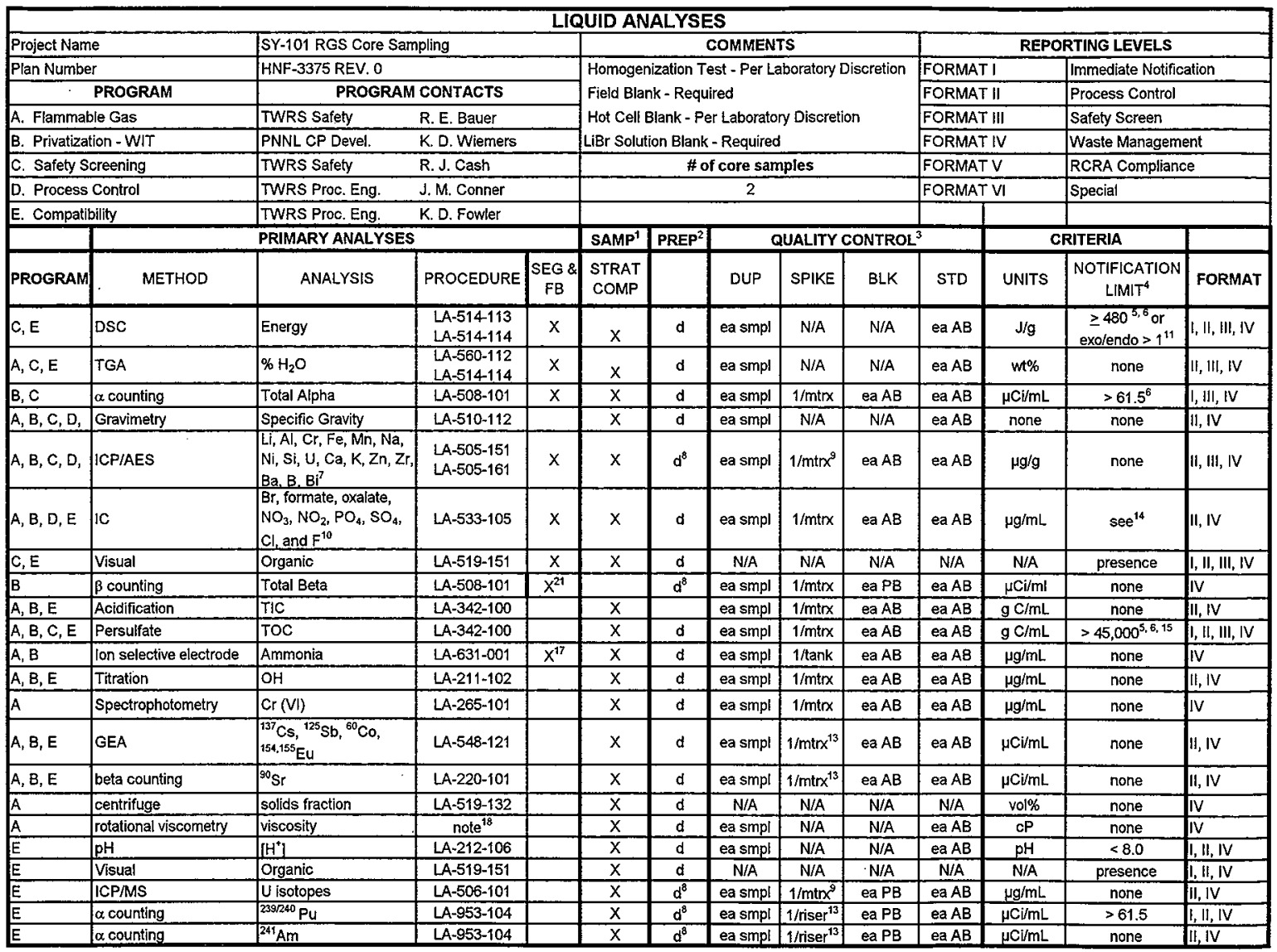


Table 2: Tank 241-SY-101 Chemical, Radiological, and Physical Analytical Requirements: Liquids

\begin{tabular}{|c|c|c|c|c|c|c|c|c|c|c|c|c|}
\hline \multirow[b]{2}{*}{ PROGRAM } & \multicolumn{3}{|c|}{ SECONDARY ANALYSES } & \multirow{2}{*}{$\begin{array}{l}\text { SAMP' } \\
\text { FB \& } \\
\text { SEG }\end{array}$} & \multirow{2}{*}{ PREP2 } & \multicolumn{4}{|c|}{ QUALITY CONTROL ${ }^{3}$} & \multicolumn{2}{|c|}{ CRITERIA } & \multirow[b]{2}{*}{ FORMAT } \\
\hline & METHOD & ANALYSIS & PROCEDURE & & & DUP & SPIKE & BLK & STD & UNITS & NOTHFICATION & \\
\hline C & $\alpha$ counting & $239 / 240 \mathrm{Pu}^{12}$ & LA-953-104 & $\mathrm{x}$ & $\bar{d}$ & ea smpl & $1 / \mathrm{mtr}^{13}$ & ea $A B$ & $e a A B$ & $\mu \mathrm{Ci} / \mathrm{g}$ & none & III, IV \\
\hline $\mathrm{C}$ & PRSST & propagating behavior & LT-510-103 & $\bar{x}$ & d & $\mathrm{N} / \mathrm{A}$ & N/A & N/A & $\operatorname{see} 20$ & $\mathrm{~J} / \mathrm{g}$ & none & IV \\
\hline
\end{tabular}

${ }^{1} \mathrm{FB}=$ fleld blank, SEG = segment-level drainable liquid, LIQ COMP = liquid stratum composite

${ }^{2} d=$ direct, $f=$ fusion, $a=$ acid, $e=$ extraction

${ }^{3} \mathrm{DUP}=$ duplicate, $\mathrm{BLK}=$ blank, $\mathrm{STD}=$ calibration standard, ea $=$ each, $\mathrm{smpl}=$ sample, $\mathrm{AB}=$ analytical batch, $\mathrm{PB}=$ preparation blank, $\mathrm{mtrx}=$ matrix, $\mathrm{N} / \mathrm{A}=$ not applicable

"Units for notification limits and expected range are those listed in the "units" column.

${ }^{5}$ Dry weight basis

${ }^{6}$ These analytes are to be compared to the limit by calculating the one-sided, upper $95 \%$ confidence limit for the sample result (to be performed by Process Engineering).

${ }^{7} \mathrm{Li}$ is required to correct $\% \mathrm{H}_{2} \mathrm{O}$ measurement (to be performed by Process Engineering). $\mathrm{Al}, \mathrm{Cr}, \mathrm{Fe}, \mathrm{Mn}, \mathrm{Na}, \mathrm{Ni}, \mathrm{Si}$, and $\mathrm{U}$ are required as secondary safety screening analytes; required if total al exceeds notification limits. $\mathrm{Na}, \mathrm{Al}, \mathrm{Cr}, \mathrm{Ca}, \mathrm{Fe}, \mathrm{K}, \mathrm{Ni}, \mathrm{Zn}, \mathrm{Zr}, \mathrm{Ba}, \mathrm{Si}, \mathrm{B}$, and $\mathrm{Bi}$ are flammable gas analytes and apply only to samples chosen to represent strata. Na and $\mathrm{Al}$ may be of interest for privatization at the segment level for evaluation of homogeneity. Results should be reported for all ICP/AES analytes, however, the QC requirements of Table 3 apply only to those identified here ${ }^{8}$ Direct liquid samples may be dilited in acid or water to adjust to proper sample size and/or $\mathrm{pH}$.

${ }^{9}$ Either serial dilutions or matrix spikes will be performed.

${ }^{10} \mathrm{Br}$ is required to correct $\% \mathrm{H}_{2} \mathrm{O}$ measurement (to be performed by Process Engineering). Formate, oxalate, $\mathrm{NO}_{3}, \mathrm{NO}_{2}, \mathrm{PO}_{4}, \mathrm{SO}_{4}, \mathrm{Cl}$, and $\mathrm{F}$ are required on stratum samples for flammable gas. $\mathrm{NO}_{3}$ may be of interest for privatization at the segment level for evaluation of homogeneity. Results should be reported for all IC analytes, but the QC requirements of Table 3 apply only to those

"Applies only to the stratum composite. If exotherm is observed, both the endotherm and exotherm values must be reported.

${ }^{12}$ Performed if total alpha exceeds notification limit.

${ }^{13}$ Tracer or carrier may be used in place of a spike and results corrected for recovery.

${ }^{14} \mathrm{For}$ DSTs with tank temperatures below $212^{\circ} \mathrm{F}$ :

a. For $\mathrm{NO}_{3} \leq 1.0 \mathrm{M}: 0.010 \mathrm{M} \leq \mathrm{OH} \leq 5.0 \mathrm{M}$ (upper $\mathrm{OH}$ limit is $8.0 \mathrm{M}$ for solutions below $167^{\circ} \mathrm{F}$, lower limit corresponds to $\mathrm{pH} 12$ in dilute solutions), $0.011 \mathrm{M} \leq \mathrm{NO}_{2} \leq 5.5 \mathrm{M}$, and $\mathrm{NO}_{3}\left(\mathrm{OH}+\mathrm{NO}_{2}\right)<2.5 \mathrm{M}$.

b. For $1.0 \mathrm{M}<\mathrm{NO}_{3} \leq 3.0 \mathrm{M}: 0.1 \times \mathrm{NO}_{3} \leq \mathrm{OH} \leq 10 \mathrm{M}$ and $\mathrm{OH}+\mathrm{NO}_{2} \geq 0.4 \times \mathrm{NO}_{3}$

c. For $\mathrm{NO}_{3}>3.0 \mathrm{M}: 0.3 \mathrm{M} \leq \mathrm{OH}<10 \mathrm{M}, \mathrm{OH}+\mathrm{NO}_{2} \geq 1.2 \mathrm{M}$, and $\mathrm{NO}_{3} \leq 5.5 \mathrm{M}$

${ }^{15} \mathrm{Corrected}$ from weight basis to volumetric basis assuming a liquid density of $1.0 \mathrm{~g} / \mathrm{mL}$.

${ }^{16}$ Furnace oxidation TOC is to be run on those samples which exhibit exotherms, but have persulfate TOC values that account for $<75 \%$ of the exotherm energy (see Equation 4 ).

${ }^{17}$ Ammonia analyses will only be performed on specified subsamples (selection will be coordinated with the TC). Analyses to be performed as rapidly as possible to minimize volatilization.

${ }^{18}$ Viscosity analyses may be conducted at PNNL or another laboratory.

${ }^{10}$ Results should be reported for all GEA analytes, however, the QC requirements of Table 4 apply only to ${ }^{137} \mathrm{Cs}$.

${ }^{20}$ PRSST may be run on the sample exhibiting the highest DSC or TOC result. Contact the tank coordinator before proceeding with this analysis.

${ }^{21}$ Total beta may be required on the segment level for evaluation of homogeneity. Analyses will be performed at the request of the tank coordinator. 
HNF-3375, REV. 0

Table 4: Tank SY-101 Analytical Requirements for LAW Privatization: Liquids

\begin{tabular}{|c|c|c|c|c|c|c|c|c|c|c|c|}
\hline \multicolumn{12}{|c|}{ LIQUID ANALYSES } \\
\hline \multicolumn{2}{|c|}{ Project Name } & \multicolumn{4}{|c|}{ SY-101 RGS Core Sampling } & \multicolumn{6}{|c|}{ COMMENTS } \\
\hline \multicolumn{2}{|c|}{ Plan Number } & & \multirow{4}{*}{\multicolumn{4}{|c|}{$\begin{array}{l}\text { Homogenization Test - Per Laboratory Discretion } \\
\text { Field Blank - Required } \\
\text { Hot Cell Blank - Per Laboratory Discretion }\end{array}$}} & \multirow{3}{*}{\multicolumn{2}{|c|}{\begin{tabular}{|l|} 
Immediate Notification \\
Process Control \\
Safety Screen \\
\end{tabular}}} \\
\hline \multirow{3}{*}{\multicolumn{2}{|c|}{ PROGRAM }} & \multicolumn{4}{|c|}{ HNF-3375 REV, 0} & & & & & & \\
\hline & & \multicolumn{4}{|c|}{ PROGRAM CONTACTS } & & & & & & \\
\hline & & \multicolumn{2}{|c|}{$+2-2$} & & & & & & & Waste Mana & gement \\
\hline \multicolumn{2}{|c|}{ A. Privatization-WIT } & PNNL CP Devel. & K.D. Wiemers & \multicolumn{2}{|c|}{ TANK } & \multicolumn{4}{|c|}{ \# of core samples } & \multicolumn{2}{|c|}{ RCRA Compliance } \\
\hline & & TWRS Proc. Eng. & J.M. Conner & & \multicolumn{4}{|c|}{2} & \multicolumn{2}{|c|}{ Special } \\
\hline \multicolumn{4}{|c|}{ PRIMARY ANALYSES } & \multirow{2}{*}{$\begin{array}{l}\text { SAMP' } \\
\text { SUP \& LIQ } \\
\text { COMP }\end{array}$} & \multirow{2}{*}{\begin{tabular}{|l|} 
PREP \\
\end{tabular}} & \multicolumn{4}{|c|}{ QUALITY CONTROL ${ }^{3}$} & CRITERIA & \multirow[t]{2}{*}{ FORMAT } \\
\hline PROGRAM & METHOD & ANALYSIS & PROCEDURE & & & DUP & SPIKE & BLK & STD & UNITS & \\
\hline A & $\alpha$ counting & Total Alpha & LA-508-101 & $\bar{x}$ & $a$ & ea smpl & $1 / \mathrm{mtn}$ & eaPB & eaAB & $\mu \mathrm{Ci} / \mathrm{mL}$ & IV \\
\hline A & Gravimetry & Specific Gravity & LA-510-112 & $\bar{x}$ & d & ea smpl & N/A & N/A & eaAB & $\mathrm{g} / \mathrm{mL}$ & IV \\
\hline A & ICPIAES & $\mathrm{see}^{7}$ & $\begin{array}{l}\text { LA-505-151 } \\
\text { LA-505-161 }\end{array}$ & $x$ & a & ea smpl & $\operatorname{see}^{9}$ & ea PB & ea $A B$ & $\mu \mathrm{g} / \mathrm{mL}$ & IV \\
\hline$\overline{\mathrm{A}}$ & ICPRMS & $\operatorname{see}^{7}$ & LT-506-101 & $\underline{x}$ & $d^{8}$ & ea smpl & $1 / \operatorname{mitrx}$ & $\mathrm{ea} \mathrm{AB}$ & $e a A B$ & $\mu \mathrm{g} / \mathrm{mL}$ & IV \\
\hline A & IC & $\operatorname{see}^{11}$ & $\begin{array}{l}\text { LA-533-105 } \\
\text { LA-533-115 }\end{array}$ & $\mathrm{x}$ & $d^{9}$ & ea smpl & $1 / \operatorname{mtrx}$ & ea $A B$ & ea $A B$ & $\mu \mathrm{g} / \mathrm{mL}$ & IV \\
\hline$A$ & \begin{tabular}{|l|} 
Ion selective electrode \\
\end{tabular} & Ammonia & LA-631-001 & $\bar{x}$ & $d^{8}$ & ea smpl & $1 /$ tank & ea $\mathrm{AB}$ & eaAB & $\mu \mathrm{g} / \mathrm{mL}^{10}$ & IV \\
\hline A & Atomic Absorption & Hg-Cold Vapor & LA-325-104 & $\bar{x}$ & $d^{8}$ & ea smpl & $1 / \operatorname{mtr} x$ & ea $A B$ & eaAB & $\mu \mathrm{g} / \mathrm{mL}$ & IV \\
\hline \multirow[t]{2}{*}{ A } & GFAA & $\mathrm{Sb}, \mathrm{Tl}$ & LA-505-102 & $\bar{x}$ & $d^{8}$ & ea smpl & $1 / m$ trx & ea $A B$ & ea $\mathrm{AB}$ & $\mu \mathrm{g} / \mathrm{mL}$ & IV \\
\hline & Colorimetric & $\mathrm{CN}$ & LA-695-102 & $x$ & $d^{3}$ & ea smpl & $1 / \mathrm{mtrx}$ & ea $\mathrm{AB}$ & ea $A B$ & $\mu \mathrm{g} / \mathrm{mL}$ & IV \\
\hline A & Gravimetric & Weight \% Solid & LA-564-101 & $\bar{x}$ & d & $\mathrm{N} / \mathrm{A}$ & N/A & $\mathrm{N} / \mathrm{A}$ & N/A & $\%$ & IV \\
\hline A & $\beta$ counting Separation & ${ }^{80} \mathrm{Sr}$ & LA-220-101 & $\bar{x}$ & $d^{3}$ & ea smpl & $\mathrm{see}^{6,8}$ & ea PB & ea $A B$ & $\mu \mathrm{Ci} / \mathrm{ml}$ & IV \\
\hline A & $\beta$ counting & Total Beta & LA-508-101 & $x$ & $d^{8}$ & ea smpl & $1 / \operatorname{mtrx}$ & ea PB & ea $A B$ & $\mu \mathrm{Ci} / \mathrm{ml}$ & IV \\
\hline A & Separtion/AEA & ${ }^{243,244} \mathrm{Cm}_{1}{ }^{241} \mathrm{Am}$ & LA-953-104 & $x$ & $d^{8}$ & ea smpl & $\mathrm{see}^{6,8}$ & ea PB & ea $A B$ & $\mu \mathrm{Ci} / \mathrm{ml}$ & IV \\
\hline $\mathrm{A}$ & Persulfate & TIC, TOC & LA-342-100 & $x$ & $d^{8}$ & ea smpl & $1 /$ mtrx & ea $A B$ & ea $A B$ & $\mathrm{~g} \mathrm{C} / \mathrm{mL}$ & IV \\
\hline$A$ & Potentiometric Titration & $\mathrm{OH}^{-}$ & LA-211-102 & $x$ & $d^{8}$ & ea smpl & $1 /$ mtrx & ea $A B$ & ea $A B$ & $\mu \mathrm{g} / \mathrm{mL}$ & IV \\
\hline$A$ & Liquid Scintillation & ${ }^{3} \mathrm{H}$ & LA-218-114 & $x$ & $d^{8}$ & ea smpl & $1 / \operatorname{mtn} x$ & $\mathrm{ea} A \mathrm{~B}$ & ea $A B$ & $\mu \mathrm{Ci} / \mathrm{mL}$ & IV \\
\hline$A$ & Liquid Scintillation & ${ }^{79} \mathrm{Se}$ & LA-365-132 & $x$ & $d^{8}$ & ea smpl & $1 / \operatorname{mtrx}$ & ea $A B$ & ea $A B$ & $\mu \mathrm{Ci} / \mathrm{mL}$ & IV \\
\hline$A$ & Liquid Scintillation & ${ }^{14} \mathrm{C}$ & LA-348-104 & $x$ & $d^{8}$ & ea smpl & $1 / \mathrm{mtrx}$ & ea $A B$ & ea $A B$ & $\mu \mathrm{Ci} / \mathrm{mL}$ & IV \\
\hline A & GEA & Full Suite & $\begin{array}{l}\text { LA-548-121 } \\
\text { LA-933-141 }\end{array}$ & $x$ & $d^{8}$ & ea smpl & $\mathrm{N} / \mathrm{A}$ & ea $A B$ & ea $A B$ & $\mu \mathrm{Ci} / \mathrm{mL}$ & IV \\
\hline $\mathrm{A}$ & Separation GEA & 129 & LA-378-103 & $x$ & $d^{8}$ & ea smpl & N/A & ea $A B$ & ea $A B$ & $\mu \mathrm{Ci} / \mathrm{mL}$ & IV \\
\hline
\end{tabular}

${ }^{1} \mathrm{LIQ}=$ liquid, COMP=composite, SUP=supernate

${ }^{2} \mathrm{~d}=$ direct, a=acid digest, e=extraction.

${ }^{3} \mathrm{DUP}=$ duplicate, $\mathrm{BLK}=$ blank, STD $=$ calibration standard, ea $=$ each, smpi $=$ sample, $\mathrm{AB}=$ analytical batch, $\mathrm{PB}=$ preparation blank, $\operatorname{mtrx}=$ matrix, $N / \mathrm{A}=$ not applicable

"Units for expected range are those listed in the "units" column.

${ }^{5}$ Gamma emitters of interest are: Cs-137, Sb-125, Co-60, Eu-154,155

${ }^{6}$ Tracer or carrier may be used in place of a spike and results corrected for recovery.

${ }^{7}$ ICP analytes of interest for Privatization (liquid composites) are: 1. (ICP/AES) Ag, Al, As, B, Ba, Be, Ca, Cd, Co, Cr, Cu, Fe, K, La, Li, Mg, Mn, Mo, Na, Ni, P, Pb,

$\mathrm{S}, \mathrm{Sb}, \mathrm{Se}, \mathrm{Si}, \mathrm{Sn}, \mathrm{Sr}$ (total), Ta, Th, Ti, U, W, V, Y, Zn, Zr. 2. (ICP/MS-duplicate methodology allowed with other analyses) Cs, Pa-231, Sn-126, Tc-99, Np-237, 
Table 4: Tank SY-101 Analytical Requirements for LAW Privatization: Liquids

Pu/Am-241, Am/Cm-243, and U, Pu, Am, and Cm isotopes. Results should be reported for all ICP/AES \& ICP/MS analytes, however, the QC requirements of Table 5 apply only to those identified here.

${ }^{8}$ These direct liquid samples may be diluted in acid or water to dissolve solids or adjust to proper sample size or $\mathrm{pH}$.

${ }^{9}$ Either serial dilutions or matrix spikes will be performed.

${ }^{10}$ Micrograms ammonia per milliliter of as-received sample.

${ }^{11}$ Ion chromatography analytes of interest for Privatization (liquid composites) are: $\mathrm{Br}, \mathrm{Cl}, \mathrm{F}, \mathrm{INO} \mathrm{NO}_{2} \mathrm{NO}_{3}, \mathrm{PO}_{4}$, and $\mathrm{SO}_{4}$.

Results should be reported for all other IC analytes obtained, but the QC requirements of Table 6 only apply to those analytes listed here. 


\subsubsection{RGS Samples for Retained Gas Analysis}

This section outlines the breakdown and analyses to be performed on core sample segments that were sampled with the RGS system and selected for retained gas analysis.

- Send selected RGS samples to the 1E-2 hot cell for RGS extraction.

- Proceed with the RGS extraction process as described in Sampling Plan for Tank 241-SY101 Retained Gas Sampler Deployment (Bates 1998). The 222-S Laboratory procedure for RGS sampler processing is LT-160-101.

The RGS gas samples collected shall be shipped to the Pacific Northwest National Laboratory (PNNL) 325 Building for analysis. Requirements for the analysis of the RGS gas samples are listed in Table 5.

Condensed phase samples collected from RGS segments may be analyzed in accordance with Tables 1 and 2 at the discretion of the tank coordinator.

\subsection{SPECIFIC METHODS AND ANALYSES}

\subsubsection{Condensed Phase Sample Analysis}

The analyses in Tables 1 through 4 to be performed on tank SY-101 core samples are based on the flammable gas, safety screening, LAW privatization, and compatibility DQOs referenced in Section 1.0, and the RGS sampling plan (Bates 1998). The laboratory procedure numbers to be used for the analyses are included in the tables. Sample preparation procedures that may be used at the 222-S Laboratory are LA-549-141 for fusion digestion, LA-505-159 or LA-505163 for acid digestion of samples, and LA-504-101 for water leach of solids.

\subsubsection{RGS Gas Sample Analysis}

The analyses performed on the RGS gas samples shall be in accordance with Bates (1998). Target analytes are listed in Table 5 . The procedure for analysis of the samples is PNL-ALO-284, "Quantitative Gas Mass Spectrometry." If a different procedure is used, this must be documented in the laboratory report. For the gas mass spectrometry analytical technique, a laboratory control standard consisting of ambient air will be analyzed once a week in duplicate. 
Table 5. Tank SY-101 RGS Analytical Requirements: Gas

\begin{tabular}{|l|l|l|l|}
\hline Analyte & PQRL (mole percent) & Precision (\%) & Accuracy (\%) \\
\hline Argon & 0.1 & 20 & 80 to 120 \\
\hline Carbon monoxide & 0.1 & 20 & 80 to 120 \\
\hline Carbon dioxide & 0.1 & 20 & 80 to 120 \\
\hline Helium & 0.1 & 20 & 80 to 120 \\
\hline Hydrogen & 0.1 & 20 & 80 to 120 \\
\hline Methane & 0.1 & 20 & 80 to 120 \\
\hline Nitrogen & 0.1 & 20 & 80 to 120 \\
\hline Oxygen & 0.1 & 20 & 80 to 120 \\
\hline Nitrous oxide & 0.1 & 20 & 80 to 120 \\
\hline $\mathrm{C}_{2} \mathrm{H}_{x}$ & -- & $\mathrm{n} / \mathrm{a}$ & n/a \\
\hline $\mathrm{C}_{3} \mathrm{H}_{x}$ & --- & $\mathrm{n} / \mathrm{a}$ & n/a \\
\hline Other hydrocarbons & --- & $\mathrm{n} / \mathrm{a}$ & $\mathrm{n} / \mathrm{a}$ \\
\hline Ammonia & --- & $\mathrm{n} / \mathrm{a}$ & n/a \\
\hline Other gases & 0.1 & 20 & 80 to 120 \\
\hline
\end{tabular}

Notes:

$\mathrm{PQRL}=$ practical reporting quantitation limit

${ }^{1}$ Precision measured by relative standard deviation or relative percent difference. Accuracy measured by recovery of standard.

\subsubsection{Solids Solubility Screening}

The LAW privatization DQO (Wiemers and Miller 1997) requires that 5 separate, identical composites be made for a solids solubility screening study. The composites should be made from the tank liquids and solids composites, combined in a ratio to match the segment with the largest amount of settled solids. Consistency between the prepared samples is to be assessed visually. The treatment conditions for the composites are the following:

1. 100 parts composite and 25 parts diluent

2. 100 parts composite and 75 parts diluent

3. 100 parts composite and 100 parts diluent

4. No treatment

5. No treatment

The diluent to be used is inhibited water. The tests are to be conducted at $25-30{ }^{\circ} \mathrm{C}$. Ambient temperature is to be recorded several times during the test. Following dilution, record 
observations, including solids properties and gelation. After a $16-\mathrm{hr}$ contact with mixing, the volume percent settled solids is to be estimated after 12 hours of settling. The solid and liquid fractions are then separated and weighed. The liquid and solids are submitted for a limited analytical set (Table 3). A mass balance is to be maintained throughout the solids screening steps.

\subsection{INSUFFICIENT SEGMENT RECOVERY}

If the amount of material recovered from samples taken from the tank is insufficient to perform the analyses requested in the SAP and permit a minimum $10 \mathrm{~mL}$ archive per sample, the laboratory shall notify the tank coordinator within one working day. A prioritization of the analyses will then be provided to the laboratory. Any analyses prescribed by this SAP, but not performed, shall be identified in the appropriate data report with justification provided for non-performance.

\subsection{QUALITY ASSURANCE AND QUALITY CONTROL}

Processes, services, activities, and conditions adverse to quality which do not conform to requirements specified in this SAP or references herein shall be controlled to prevent inadvertent use. Nonconforming sampling and analysis processes shall be identified, controlled, reported, and dispositioned as required by the Nonconforming Item Reporting and Control (PHMC 1997).

\subsection{SAMPLE COLLECTION}

Before sampling can be performed on a tank, available risers must be identified for use in the sampling event. The selected risers must be inspected and prepared to confirm their ability to be used in sampling. Safety hazards must be identified and special precautions must be taken if needed. Video surveillance during core sampling has been requested to determine whether any gas is released from the waste during sampling (Bates 1998). Videotape is needed during crust sampling (the first four segments of each core).

Samples are to be taken from a tank and shipped to the performing laboratory by $\mathrm{CPO}$ in accordance with the respective work packages. The chain-of-custody form for this work package shall identify samples by a unique number and state the type of sampler used (retained gas sampler or universal sampler) for each sample before being shipped to the 222-S Laboratory. Approved procedure TO-080-090 [Load/Transport Sample Cask(s)] is to be used during the sampling event. Pertinent sampling information (e.g. unusual waste characteristics, $X$-ray scan results, or detecting possible debris) should be noted in the comment section of the chain-of-custody form.

Characterization Project Operations should transport each universal sample collected to the performing laboratory within 3 calendar days of removing the sample from the tank. RGS samples should be transported to the laboratory within 24 hours of removing the sample from 
the tank. A verbal notification by CPO is to be made to the 222-S Laboratory at $373-2435$ at least 24 hours in advance of an expected shipment.

\subsection{SAMPLE CUSTODY}

The chain-of-custody form is initiated by the sampling team as described in the work package. Samples are shipped in a cask and sealed with a Waste Tank Sample Seal (see below).

\begin{tabular}{|l|l|}
\hline $\mathrm{S}+4$ & WASTE TANK SAMPLE SEAL \\
\hline Supervisor & Sample No.: \\
\hline Date of Sampling: & Time of Sampling: \\
\hline Shipment No.: & Serial No.: \\
\hline
\end{tabular}

Each sample number shall be created using the sample's core and segment number. For instance, segment 1 of core 197 would be sample number 197-01. The sealed and labeled samples are shipped to the laboratory along with the chain-of-custody form. The receipt and control of samples in the 222-S Laboratory are described in laboratory procedure LO-090-101.

\subsection{LABORATORY OPERATIONS}

\subsubsection{Quality Assurance}

Laboratories performing analyses in support of this SAP shall have approved and implemented Quality Assurance (QA) plans. 222-S Laboratory Quality Assurance Plan (Markel 1997) specifies the requirements for assuring the quality of sample analysis conducted at the 222-S Laboratory. Requirements for samples analyzed at PNNL are described in Quality Assurance Plan for Activities conducted by the Analytical Chemistry Laboratory $(A C L)$ (Bredt and KuhlKlinger 1996). These QA plan meets the Hanford Analytical Services Quality Assurance Requirements Document (DOE 1997) minimum requirements as the baseline for laboratory quality systems. Quality requirements for conducting Characterization Project sampling and analysis are described in Tank Waste Remediation System Characterization Project, Quality Policies (Board 1997) and this SAP. Characterization Project sampling and analysis shall be conducted in conformance with these quality assurance requirements.

\subsubsection{Quality Control}

Performing laboratories shall implement a documented system of quality control (QC) to ensure that data generated for this project will be of known and documented quality. Laboratory standard operating procedures shall specify qualitative and quantitative acceptance criteria for QC activities and corrective action measures to be taken when QC criteria are not satisfied. Additional or more stringent requirements may be required by the customer. 
HNF-3375, Rev. 0

The formalized QC system shall include initial equipment calibration; periodic calibration verification; and analysis of laboratory duplicates, blanks, spikes, and control samples (see DOE [1997] for definitions of QC samples and standards). This QC system will document that the analytical process is in a state of control while actual samples are being analyzed, that precision and accuracy requirements have been met, and that the measurement system is free of contamination. Analytical quality control (QC) requirements (duplicates, spikes, blanks, laboratory control samples) are identified in Tables 1 through 6.

If sample QC failures occur or if all analyses cannot be performed (e.g., insufficient sample), analysts shall consult with supervisors/customers to determine the proper action. The laboratory should provide a suggested course of action at that time. All sample QC failures and limitations on the associated data shall be discussed in the narrative of the data report. Proper notification of all data not meeting QC requirements shall be included with the data. 
HNF-3375, Rev. 0

Table 6. QC Precision and Accuracy Requirements for the Condensed Phase Analyses

\begin{tabular}{|c|c|c|c|c|}
\hline Analysis/Method & $\begin{array}{l}\text { Duplicate } \\
\text { Criteria (RPD) }\end{array}$ & $\begin{array}{l}\text { Spike } \\
\text { Griteria } \\
\text { (\% recovery) }\end{array}$ & $\begin{array}{c}\text { Preparation } \\
\text { Blank } \\
\text { Criteria' }\end{array}$ & $\begin{array}{l}\text { Lcs Criteria } \\
\text { (\% recovery) }\end{array}$ \\
\hline \multicolumn{5}{|l|}{ Solids : } \\
\hline DSC & $\leq 30$ & $\mathrm{~N} / \mathrm{A}$ & N/A & $80-120$ \\
\hline TGA & $\leq 30$ & $\mathrm{~N} / \mathrm{A}$ & N/A & $80-120$ \\
\hline Wt\% solid & N/A & $\mathrm{N} / \mathrm{A}$ & $\mathrm{N} / \mathrm{A}$ & N/A \\
\hline $\mathrm{OH}^{-}$ & $\leq 10$ & $75-125$ & $<\mathrm{EQL}$ & $90-110$ \\
\hline Bulk density & N/A & N/A & $\mathrm{N} / \mathrm{A}$ & N/A \\
\hline Total alpha & $\leq 20$ & $75-125$ & $<\mathrm{MDA}$ & $70-130$ \\
\hline ICP/AES & $\leq 20$ & $75-125$ & $<\mathrm{EQL}$ & $80-120$ \\
\hline $\mathrm{Na}(\mathrm{ICP})$ for $\mathrm{LAW}$ & $\leq 5$ & $75-125$ & $<\mathrm{EQL}$ & $80-120$ \\
\hline IC & $\leq 20$ & $75-125$ & $<\mathrm{EQL}$ & $80-120$ \\
\hline TOC & $\leq 20$ & $75-125$ & $<\mathrm{EQL}$ & $80-120$ \\
\hline${ }^{90} \mathrm{Sr}$ & $\leq 20$ & $75-125^{5}$ & $<\mathrm{MDA}$ & $80-120$ \\
\hline GEA & $\leq 20$ & N/A & $<\mathrm{MDA}$ & $80-120$ \\
\hline${ }^{239 / 240} \mathrm{Pu}$ & $\leq 20$ & $75-125^{5}$ & $<\mathrm{MDA}$ & $70-130$ \\
\hline PRSST & N/A & N/A & $\mathrm{N} / \mathrm{A}$ & N/A \\
\hline $\mathrm{Cr}(\mathrm{VI})$ & $\leq 20$ & $75-125$ & $<\mathrm{EQL}$ & $80-120$ \\
\hline Ammonia & $\leq 10$ & $75-125$ & $<\mathrm{EQL}$ & $90-110$ \\
\hline GC/MS & \multicolumn{4}{|c|}{ see note 8} \\
\hline $\mathrm{ICP} / \mathrm{MS}^{5}$ & $\leq 20$ & $75-125$ & $<\mathrm{MDA}$ & $80-120$ \\
\hline TIC & $\leq 20$ & $75-125$ & $<\mathrm{EQL}$ & $80-120$ \\
\hline Sep.AEA $\left({ }^{241} \mathrm{Am}\right)$ & $\leq 20$ & N/A & $<\mathrm{MDA}$ & $80-120$ \\
\hline Viscosity & $\begin{array}{c}\leq 10(10-50 \mathrm{cP}) \\
\leq 50\left(10^{2}-10^{8} \mathrm{cP}\right) \\
\end{array}$ & N/A & N/A & $75-125$ \\
\hline Shear strength & N/A & N/A & N/A & N/A \\
\hline Solids fraction & N/A & N/A & N/A & N/A \\
\hline
\end{tabular}


Table 6. QC Precision and Accuracy Requirements for the Condensed Phase Analyses

\begin{tabular}{|c|c|c|c|c|}
\hline Analysis/Method & $\begin{array}{l}\text { Duplicate } \\
\text { Criteria (RPD) }\end{array}$ & $\begin{array}{c}\text { Spike } \\
\text { Criteria } \\
(\% \text { recovery })^{2}\end{array}$ & $\begin{array}{l}\text { Preparation } \\
\text { Blank } \\
\text { Criteria }^{3}\end{array}$ & $\begin{array}{l}\text { LCSCriteria } \\
\text { (\% recovery) }\end{array}$ \\
\hline \multicolumn{5}{|l|}{ Liquids: } \\
\hline DSC & $\leq 20$ & N/A & N/A & $80-120$ \\
\hline TGA & $\leq 20$ & N/A & N/A & $80-120$ \\
\hline Weight \% solid & $\leq 20$ & N/A & N/A & $\mathrm{N} / \mathrm{A}$ \\
\hline Specific gravity & $\leq 10$ & $\mathrm{~N} / \mathrm{A}$ & N/A & N/A \\
\hline Total alpha & $\leq 20$ & $75-125$ & $<\mathrm{MDA}$ & $70-130$ \\
\hline Total beta & $\leq 20$ & $75-125$ & $<$ MDA & $70-130$ \\
\hline ICP/AES & $\leq 20$ & $75-125$ & $<\mathrm{EQL}$ & $80-120$ \\
\hline $\mathrm{Na}$ (ICP) for LAW & $\leq 5$ & $75-125$ & $<E Q L$ & $80-120$ \\
\hline $\mathrm{Hg}$ & $\leq 20$ & $75-125$ & $<\mathrm{EQL}$ & $80-120$ \\
\hline IC & $\leq 20$ & $75-125$ & $<\mathrm{EQL}$ & $80-120$ \\
\hline TOC & $\leq 20$ & $75-125$ & $<\mathrm{EQL}$ & $80-120$ \\
\hline${ }^{90} \mathrm{Sr}$ & $\leq 20$ & $75-125^{5}$ & $<\mathrm{MDA}$ & $80-120$ \\
\hline Liq Scin. $\left({ }^{19} \mathrm{Se}\right)$ & $\leq 20$ & N/A & $<\mathrm{MDA}$ & $\mathrm{NP}$ \\
\hline Sep.GEA $\left({ }^{129} \mathrm{~T}\right)$ & $\leq 20$ & $75-125$ & $<\mathrm{MDA}$ & $80-120$ \\
\hline${ }^{239 / 240} \mathrm{Pu}$ & $\leq 20$ & $75-125^{5}$ & $<\mathrm{MDA}$ & $70-130$ \\
\hline $\mathrm{Cr}(\mathrm{VI})$ & $\leq 20$ & $75-125$ & $<\mathrm{EQL}$ & $80-120$ \\
\hline Ammonia & $\leq 10$ & $75-125$ & $<\mathrm{EQL}$ & $90-110$ \\
\hline TIC & $\leq 20$ & $75-125$ & $<\mathrm{EQL}$ & $80-120$ \\
\hline $\mathrm{pH}$ & $\leq 20$ & N/A & N/A & $\pm 0.1 \mathrm{pH}$ units \\
\hline $\mathrm{OH}$ & $\leq 10$ & $75-125$ & $<\mathrm{EQL}$ & $90-110$ \\
\hline GEA $\left({ }^{60} \mathrm{Co}\right)$ & $\leq 20$ & $75-125$ & $<\mathrm{MDA}$ & $80-120$ \\
\hline $\begin{array}{l}\text { GEA } \\
\left({ }^{125} \mathrm{Sb},{ }^{137} \mathrm{Cs},{ }^{154,155} \mathrm{Eu}\right)\end{array}$ & $\leq 20$ & N/A & $<\mathrm{MDA}$ & NP \\
\hline Sep. Liq Scin. $\left({ }^{3} \mathrm{H}\right)$ & $\leq 20$ & $\mathrm{~N} / \mathrm{A}$ & $<\mathrm{MDA}$ & $80-120$ \\
\hline Sep. Liq Scin. $\left({ }^{14} \mathrm{C}\right)$ & $\leq 20$ & N/A & $<\mathrm{MDA}$ & NP \\
\hline
\end{tabular}


HNF-3375, Rev. 0

Table 6. QC Precision and Accuracy Requirements for the Condensed Phase Analyses

\begin{tabular}{|c|c|c|c|c|}
\hline Analysis/Method & $\begin{array}{l}\text { Diuplicate } \\
\text { Criteria (RPD) }\end{array}$ & $\begin{array}{c}\text { Spike } \\
\text { Criteria } \\
(\% \text { recovery })^{2}\end{array}$ & $\begin{array}{l}\text { Preparation } \\
\text { Blank } \\
\text { Criteria }\end{array}$ & $\begin{array}{l}\mathrm{CS} \text { Criteria } \\
(\% \text { recovery })\end{array}$ \\
\hline Sep.AEA $\left({ }^{243 / 244} \mathrm{Cm}\right)$ & $\leq 20$ & N/A & $<\mathrm{MDA}$ & $80-120$ \\
\hline Sep.AEA $\left({ }^{241} \mathrm{Am}\right)$ & $\leq 20$ & N/A & $<\mathrm{MDA}$ & $80-120$ \\
\hline ICP/MS ${ }^{5,6}$ & $\leq 20$ & $70-130$ & $<\mathrm{MDA}$ & $80-120$ \\
\hline $\mathrm{ICP} / \mathrm{MS}^{5,7}$ & $\leq 20$ & $75-125$ & $<\mathrm{MDA}$ & $90-110$ \\
\hline GFAA (Sb, Tl) & $\leq 20$ & $75-125$ & $<\mathrm{EQL}$ & $80-120$ \\
\hline Colorimetry $(\mathrm{CN})$ & $\leq 20$ & $75-125$ & $<\mathrm{EQL}$ & $80-120$ \\
\hline PRSST & N/A & N/A & N/A & $\mathrm{N} / \mathrm{A}$ \\
\hline Viscosity & $\begin{array}{c}\leq 10(10-50 \mathrm{cP}) \\
\leq 50\left(10^{2}-10^{8} \mathrm{cP}\right)\end{array}$ & N/A & N/A & $75-125$ \\
\hline Settling rate & $\leq 10$ & N/A & N/A & N/A \\
\hline $\begin{array}{l}\text { N/A } \\
\text { MDA } \\
\text { LCS } \\
\text { Sep } \\
\text { TOC } \\
\text { NP } \\
\text { ICP/AES } \\
\text { ICP/MS }\end{array}$ & $\begin{array}{l}=\text { not applicable } \\
=\text { minimum detectable activ } \\
=\text { laboratory control standar } \\
=\text { separation } \\
=\text { total organic carbon } \\
=\text { not performed } \\
\mathrm{S}\end{array}$ & $\begin{array}{l}\mathrm{AEA}=\mathrm{al} \\
\mathrm{EQL}=\mathrm{es} \\
\mathrm{Scin}=\mathrm{sc} \\
\mathrm{TIC}=\mathrm{to} \\
\mathrm{GEA}=\mathrm{ga}\end{array}$ & $\begin{array}{l}\text { a energy analysis } \\
\text { mated quantitation } \\
\text { atillation } \\
1 \text { inorganic carbon } \\
\text { ama energy analys } \\
\text { spectroscopy } \\
\text { y }\end{array}$ & \\
\hline
\end{tabular}

${ }^{\mathrm{l}}$ For the calculation of the relative percent difference (RPD), both the sample and duplicate results must exceed the EQL or MDA. Failures are permissible if the requirements in the QA section are followed.

${ }^{2}$ The criteria are recommended. Failures are permissible if the requirements in the QA section are followed.

${ }^{3}$ When a blank exceeds the EQL or MDA, sample results that exceed the contribution from the blank twenty-fold or more are reportable. See also the QA section of this SAP.

${ }^{4}$ For some analyses, this could be a method spike or a blank spike. Ranges are percent recovery of theoretical.

${ }^{5} \mathrm{~A}$ tracer or carrier may be substituted for the spike.

${ }^{6} \mathrm{ICP} / \mathrm{MS}\left({ }^{99} \mathrm{Tc},{ }^{241} \mathrm{Pu} / \mathrm{Am},{ }^{238,239,240,242} \mathrm{Pu},{ }^{126} \mathrm{Sn},{ }^{231} \mathrm{~Pa},{ }^{238} \mathrm{U}\right)$

${ }^{7} \mathrm{ICP} / \mathrm{MS}\left({ }^{243} \mathrm{Am} / \mathrm{Cm},{ }^{237} \mathrm{~Np},{ }^{233,234,235,236} \mathrm{U}\right)$

${ }^{8}$ Refer to DOE (1998) for a discussion of the criteria for this method.

\subsubsection{Specific RGS Gas Analysis Requirements}

These analytical and data handling requirements, which are specific to the RGS gas analysis, were taken from Bates (1998).

The LCS for the gas mass spectrometry analytical technique will be ambient air. The LCS will be analyzed in duplicate, weekly. 
For the gas mass spectrometry analytical technique, precision is measured daily by analyzing "pure" nitrogen in triplicate. The accuracy of analysis is determined by summing the partial pressures of the gases and comparing the result to the total pressure. The determination that corrective action is necessary is based upon the comparison of partial pressure to total pressure. If the pressures are not comparable, then corrective action is taken. Analyte identification is based upon spectral fingerprints. Any analyte of interest exhibiting a reliable spectra is reported.

Records kept by the performing laboratories shall document that measurement systems are properly calibrated; that instrumentation is being properly maintained; that, periodically, air samples and, semi-annually, "pure" gases are analyzed; and results compared to literature reference values; that calibration standards are traceable to national standards; that data reduction has been properly performed; that personnel performing work have been properly trained; that samples were analyzed according to established operating procedures; and that quality control systems and criteria were in place and met at the time of actual sample analysis.

These records shall be kept, organized, protected, and maintained in a manner that ensures their retrieval and review. Records kept in conjunction with the analysis of actual project samples shall be available for review by the customer.

Sufficient records shall be kept by the performing laboratories to enable the customer or the customer's representatives to verify the reported data and its quality and to determine who performed the analysis on what equipment on what date and time.

Analysis data must be reviewed and approved prior to release to the customer. One hundred percent of the data must receive an independent technical review by a qualified individual other than the data generator. This review process must be documented and conducted according to standard procedures. The reviewers must release the data, as evidenced by signature, and, as a consequence, ensure the following:

- Data generation and reduction were conducted in a technically correct manner in accordance with the methods used. Data were reported in the proper units and to the correct number of significant figures.

- Calculations have been verified by a valid calculation program, a spot check of verified calculation programs, and/or 100-percent check of all calculations.

- All variances from the accepted method and the rationale for the variations haver been documented and approved.

- The data have been reviewed for transcription errors.

- The analytical QC data documentation is complete and includes raw data, calculation records, Chain of Custody forms, calibration records, and QC sample analysis results. 
- QC sample analysis results are within established control limits, and if not, the data have been qualified supported by adequate explanation.

- Sample holding time requirements, if any, and data reporting requirements, if any, were met or exceptions documented.

Any difficulties, QC problems, reanalyses, or other pertinent informatinon regarding the analysis procedure shall be included in a narrative describing these events.

\subsection{EXCEPTIONS, CLARIFICATIONS, AND ASSUMPTIONS}

\subsection{EXCEPTIONS TO DQO REQUIREMENTS}

The safety screening DQO (Dukelow et al. 1995) states that cyanide analysis is required when the energetics notification limit is exceeded and the total organic carbon (TOC) is less than its notification limit. Because the ferrocyanide safety issue has been closed, cyanide analysis is no longer required as a secondary analyte under the safety screening DQO (Cash 1997).

The safety screening DQO requires analyses at the half-segment level for solids and at the segment level for liquids. However, the DQO is being applied on an opportunistic basis, so the subsampling scheme will be dictated by other DQOs. Therefore, the safety screening analyses will be performed on segment level solids and liquids.

Analysis by the RSST method is currently required as a secondary analyte by the safety screening DQO. However, since the issuance of the DQO, the PRSST has replaced the RSST analysis requirement. Therefore, the PRSST method is listed as a secondary analysis in Tables 1 and 2 .

Analysis for organics, N-methyl-benzenamine, pyrene, 1,2-trans-dichloroethene, dioxins and furans will not be performed. At this time, the method used to analyze these organics are not developed. These organic analytes will be considered under the next revision of the LAW DQO.

In the LAW DQO, homogeneity testing of the liquid samples is required. To determine homogeneity, analyses for $\mathrm{Na}, \mathrm{Al}, \mathrm{NO}_{3}$, and total alpha shall be performed. In addition to these analyses, a request for total beta analysis as part of the homogeneity testing has been made. Although this requirement is not included in the LAW DQO, it is necessary and, as such, has been included in Table 4 . 


\subsection{CLARIFICATIONS AND ASSUMPTIONS}

A number of clarifications and assumptions relating to the analyses, notification limits or decision thresholds identified in the applicable DQO efforts need to be made with respect to the analyses in Tables 1 through 4 . Each of these issues is discussed below:

- Ammonia analysis on residual sample remaining after RGS gas extraction is requested by Bates (1998). For comparison, ammonia analyses should also be conducted on non-RGS samples. To limit the loss of ammonia from the samples, solids samples should be prepared by a room-temperature water digest. Handling should be minimized (e.g. ammonia analyses should be conducted before other analyses such as ICP and IC, if practical). Ammonia analyses are specified in Tables 1 through 4.

- Any exothermic reaction determined by DSC must be reported on a dry weight basis as shown in equation 1 using the weight percent water determined from thermogravimetric analysis (TGA).

$$
\text { Exotherm (dry wt) }=\frac{[\text { exotherm }(\text { wet wt }) \times 100]}{(100-\% \text { water })}
$$

NOTE: A large error in the DSC value may result when converting samples containing greater than 90 percent water to a dry weight basis. However, this conversion is still required.

- The safety screening DQO (Dukelow et al. 1995) requires that additional analyses be performed if total alpha activity is greater than $1 \mathrm{~g} / \mathrm{L}$. For solids, total alpha activity is measured in $\mu \mathrm{Ci} / \mathrm{g}$ rather than $\mathrm{g} / \mathrm{L}$. To convert the notification limit for total alpha activity into a number more readily usable by the laboratory, it was assumed that all alpha decay originates from ${ }^{239} \mathrm{Pu}$. The notification limit may then be calculated as shown in equation 2:

$$
\left(\frac{\mathrm{lg}}{\mathrm{L}}\right)\left(\frac{1 \mathrm{~L}}{10^{3} \mathrm{~mL}}\right)\left(\frac{1}{\text { density }} \frac{\mathrm{mL}}{\mathrm{g}}\right)\left(\frac{0.0615 \mathrm{Ci}}{1 \mathrm{~g}}\right)\left(\frac{10^{6} \mu \mathrm{Ci}}{1 \mathrm{Ci}}\right)=\frac{61.5}{\text { density }} \frac{\mu \mathrm{Ci}}{\mathrm{g}}
$$

NOTE: Solid samples measured for total alpha activity shall also be measured for density. The notification limit for solid subsamples shall be $41 \mu \mathrm{Ci} / \mathrm{g}$ until the density is measured. At such time, the notification limit will be adjusted according to equation 2 and the total alpha activity results will be reevaluated against the new limit.

- The safety screening DQO (Dukelow et al. 1995) states that the analytical results should be compared to their notification limits at a $95 \%$ confidence level (one-tailed test). The equation for determining the upper confidence value is shown in equation 3. 


$$
\hat{\mu}+t_{(\mathbf{n}-1)} * \frac{\sqrt{\sigma^{2}}}{\sqrt{n}}
$$

Where $\hat{\mu}$ is the sample mean, $\hat{\sigma}^{2}$ is the sample variance, $\mathrm{n}$ is the number of observations (for a sample run in duplicate, $n$ equals 2 ), and $t_{(n-1)}$ is the quantile from Student's $t$ distribution with ( $\mathrm{n}-1)$ degrees of freedom (for a one-sided $95 \%$ confidence interval and when $\mathbf{n}$ is $2, t$ is 6.314). This equation is appropriate for confidence limit estimates of the mean when the sample size is small. This equation, as well as a table of values for the Student $t$ statistic, should be found in any introductory statistics textbook (e.g., Lapin 1983).

The laboratory is requested to report all analytical results recovered from the GEA, ICP, and IC analyses, even though only specific analytes are requested. These opportunistic analyses (Kristofzski 1996) should be reported only if no additional preparatory work is required (e.g., running additional standards) and if the error associated with the results are documented. No reruns nor additional analyses should be performed to improve recovery for analytes not specifically requested in Tables 1 through 4 .

\subsection{ORGANIZATION}

The organization and responsibility of key personnel involved with this tank SY-101 characterization project are listed in Table 7 .

Table 7. Tank SY-101 Project Key Personnel

\begin{tabular}{|l|l|l|}
\hline \multicolumn{1}{|c|}{ Responsibility } & \multicolumn{1}{|c|}{ Organization } & \multicolumn{1}{|c|}{ Individual } \\
\hline $\begin{array}{l}\text { Tank SY-101 tank } \\
\text { coordinator }\end{array}$ & $\begin{array}{l}\text { Process Engineering } \\
\text { (LMHC) }\end{array}$ & J. M. Conner, 373-2711 \\
\hline RGS point of contact & PNNL Fluid Dynamics & J. M. Bates, 375-2539 \\
\hline $\begin{array}{l}\text { 222-S Laboratory point of } \\
\text { contact, day shift }\end{array}$ & Analytical Services (WMH) & D. B. Hardy, 376-4878 \\
\hline $\begin{array}{l}\text { 222-S Laboratory point of } \\
\text { contact, off-hours }\end{array}$ & Analytical Services (WMH) & $\begin{array}{l}\text { 222-S Laboratory shift } \\
\text { manager, 373-2435 }\end{array}$ \\
\hline $\begin{array}{l}\text { Single shell tank point of } \\
\text { contact }\end{array}$ & Tank Farm Operations & $\begin{array}{l}\text { Single shell tank operations } \\
\text { shift manager, 373-3475 }\end{array}$ \\
\hline
\end{tabular}




\subsection{DELIVERABLES}

All condensed phase analyses will be reported as Format I, II, III, or IV as indicated in Tables 1 through 4. Vapor results will be reported as Format VI (See Section 7.4). Additional information regarding reporting formats is given in Schreiber (1998).

\subsection{FORMAT I REPORTING}

Tables 1 through 4 contain the notification limits for each analyte. Any results exceeding their notification limits shall be reported via telephone by the 222-S Laboratory shift manager to the single shell tank operations shift manager as soon as the data are obtained and reviewed by the responsible scientist. This verbal notification must be followed within one hour by electronic notification to the tank farm operations shift manager, the TWRS Process Engineering Data Assessment and Interpretation manager, and the tank coordinator responsible for the tank. Additional analyses for verification purposes may be contracted between the performing laboratory and the tank coordinator by either a revision to this SAP or by a letter.

\subsection{FORMAT II REPORTING}

A letter report documenting the results of the analyses shall be issued to the TWRS Process Engineering Data Assessment and Interpretation manager, the tank coordinator responsible for the tank, and the Tank Farm Compatibility point of contact within 90 days of the receipt of the sample at the laboratory loading dock. The format II report is not required to contain supporting raw data, QC results, or associated analytical procedure numbers. However, the results require review and approval by the cognizant scientist or manager of the laboratory operation.

\subsection{FORMAT III REPORTING}

Analyses identified as primary safety screening analyses in Tables 1 and 2 must be completed within $\mathbf{4 5}$ calendar days of the receipt of the last sample at the laboratory sample receiving/loading dock. If no safety screening criteria were exceeded, the laboratory shall electronically notify the tank coordinator and shall follow the notification with a letter to the TWRS Process Engineering Data Assessment and Interpretation manager and the tank coordinator confirming work completion. If any analysis results exceeded the safety screening criteria, a letter identifying the results which exceeded the criteria will be issued.

Any secondary safety screening analyses must be completed within 90 calendar days of the receipt of the last sample at the laboratory sample receiving/loading dock. When the secondary analyses are complete, the laboratory shall issue a letter to the TWRS Process Engineering Data Assessment and Interpretation manager and tank coordinator confirming work completion. If any secondary analysis notification limits were exceeded, the results which exceeded the limits shall be identified. 


\subsection{FORMAT IV REPORTING}

The format IV report shall be a data package reporting the results of analyses performed and will resemble a regulatory data package without third party validation. The data package should be prepared by tank and include the data for all samples, including (as applicable) composites, segments, subsegments, drainable liquids, and associated blanks taken and analyzed for this sampling event. The recommended reporting format and the raw data that shall be included are given in detail in Section A5.0 of Schreiber (1998). This data package shall be issued as a document approved for public release through the document control system within 180 calendar days of the receipt of the last sample at the laboratory sample receiving/loading dock. The raw data shall be accessible to the program in accordance with the laboratory's Records Inventory and Disposition Schedule and until the respective waste tank is closed or the waste is treated.

In addition to this data package, an electronic version of the analytical results shall be provided to the Tank Characterization Database representative on the same day that the final data package is issued. The data must be available to the Washington State Department of Ecology within 7 days of release of the data package. The electronic version shall be in the standard electronic format (Bobrowski et al. 1994).

\subsection{FORMAT VI REPORTING}

The Format VI report shall present the RGS and vapor grab sample results. The report shall be issued by the performing laboratory to designated Flammable Gas Project Personnel. Report content shall be in accordance with the Sampling Plan for Tank 241-SY-101 Retained Gas Sampler Deployment (Bates 1998).

\subsection{CHANGE CONTROL}

Under certain circumstances, it may become necessary for the performing laboratory to make decisions concerning a sample without review of the data by the customer or the Characterization Project. All significant changes (such as DQO additions or analysis of new, additional samples) shall be coordinated by TWRS Process Engineering and documented via an engineering change notice to this SAP or by a letter. All changes shall also be clearly documented in the final data package. Insignificant changes (such as changes in procedure numbers) may be made by the tank or project coordinator by placing a notation in the permanent record (e.g., data package, extrusion $\log$ book, or memo to file). Significance is determined by the tank coordinator. 


\subsection{REFERENCES}

Bates, J. M., 1998, Sampling Plan for Tank 241-SY-101 Retained Gas Sampler Deployment, TWS98.75 Rev. 1, Pacific Northwest National Laboratory, Richland, Washington.

Bauer, R. E., 1998, Data Quality Objective to Support Resolution of the Flammable Gas Safety Issue, HNF-SD-WM-DQO-004, Rev. 3A, Duke Engineering \& Services Hanford, Inc., Richland, Washington.

Board, D. C., 1998, Tank Waste Remediation System, Characterization Project, Quality Policies, HNF-SD-WM-QAPP-025, Rev. 4, Lockheed Martin Hanford Corporation, Richland, Washington.

Bobrowski, S. F., S. J. Harris, and J. D. Schwab, 1994, Standard Electronic Format Specification for Tank Characterization Database Loader, Version 2.0, (memorandum TCD-94-002 to C. S. Haller, June 16), Pacific Northwest Laboratory, Richland, Washington.

Bredt, O. P., and K. J. Kuhl-Klinger, 1996, Quality Assurance Plan for Activities conducted by the Analytical Chemistry Laboratory $(A C L)$, MCS-033, Rev. 4, Pacific Northwest National Laboratory, Richland, Washington.

Brown, T. M., J. W. Hunt, and L. J. Fergestrom, 1998, Tank Characterization Technical Sampling Basis, HNF-SD-WM-TA-164, Rev. 4, Lockheed Martin Hanford Corporation, Richland, Washington.

Cash, R. J., 1997, Cancellation of Total Cyanide Requirements, (letter 2N160-97-012 to J. G. Kristofzski, June 16), DE\&S Hanford, Incorporated, Richland, Washington.

Cash, R. J., 1998a, "Retained Gas Sampling for Tank 241-SY-101" (Interoffice Memo 2N160-65-017 to M. A. Payne, September 24) DE\&S Hanford, Incorporated, Richland, Washington.

Cash, R. J., 1998b, "Application of Flammable Gas DQO" (Internal Memo SIR-98-3-01 to K. M. Hall, March 3), DE\&S Hanford, Incorporated, Richland, Washington.

Conner, J. M., and G. M. Koreski, 1998, Quarterly Review of 241-SY-101 Mixer Pump Data: April - June, 1998, HNF-3402, Lockheed Martin Hanford Corporation, Richland, Washington.

Certa, P. J., 1998, Data Quality Objectives for TWRS Privatization Phase I: Confirm Tank T is an Appropriate Feed Source for Low-Activity Waste Feed Batch X, HNF-1796, Rev. 0, Numatec Hanford Corporation, Richland, Washington.

DOE, 1997, Hanford Analytical Services Quality Assurance Requirements Document, DOE/RL-96-68, Rev. 1, U.S. Department of Energy, Richland Field Office, Richland, Washington. 
DOE 1998, "Contract Number DE-AC06-96RL13200-Performance Agreements (PA)

TWR1.2.15 and TWR1.2.16," Letter 98-SCD-027, Sally A. Sieracki (DOE) to H. J. Hatch, (FDH), U. S. Department of Energy, Richland Field Office, Richland, Washington.

Dukelow, G. T., J. W. Hunt, H. Babad, and J. E. Meacham, 1995, Tank Safety Screening Data Quality Objective, WHC-SD-WM-SP-004, Rev. 2, Westinghouse Hanford Company, Richland, Washington.

Hanlon, B. M., 1998, Waste Tank Summary Report for Month Ending March 31, 1998, HNF-EP-0182-120, Lockheed Martin Hanford Corporation, Richland, Washington.

Jo, J., 1998, Application of "Confirm Tank $T$ is an Appropriate Feed Source for Low-Activity Waste Feed Batch X" to Specific Feed Batches, HNF-2799, Rev. 0, Lockheed Martin Hanford Corporation, Richland, Washington.

Kristofzski, J. G., 1996, Directions for “Opportunistic Analyses, " (memorandum 75310-96-168 to J. H. Baldwin, et al., September 11), Westinghouse Hanford Company, Richland, Washington.

Lapin, L. L., 1983, Probability and Statistics for Modern Engineering, Brooks/Cole Publishing Company, Monterey, California.

Markel, L. P., 1997, 222-S Laboratory Quality Assurance Plan, HNF-SD-CP-QAPP-016, Rev. 2, Rust Federal Services of Hanford, Inc., Richland, Washington.

Mulkey, C. H, and M. S. Miller, 1997, Data Quality Objectives for Tank Farm Waste Compatibility Program, HNF-SD-WM-DQO-001, Rev. 2, Lockheed Martin Hanford Corporation, Richland, Washington.

PHMC, 1997, Nonconforming Item Reporting and Control, HNF-PRO-298, Rev. 0, Fluor Daniel Hanford Company, Richland, Washington.

Schreiber, R. D., 1998, Fiscal Year 1998 Memorandum of Understanding for the TWRS Characterization Project, HNF-2245, Rev. 0, Lockheed Martin Hanford Corporation, Richland, Washington.

Schreiber, R. D., 1997, Memorandum of Understanding for the Organic Complexant Safety Issue Data Requirements, HNF-SD-WM-RD-060, Rev. 0, Lockheed Martin Hanford Corporation, Richland, Washington.

Simpson, B. C., and D. J. McCain, 1997, Historical Model Evaluation Data Requirements, HNF-SD-WM-DQO-018, Rev. 2, Lockheed Martin Hanford Corporation, Richland, Washington.

White, M., September, 1996, "Retained Gas Sampler Lab Tests," TWSMIT:090596, Pacific Northwest National Laboratory, Richland, Washington. 
HNF-3375, Rev. 0

Wiemers, K. D., and M. S. Miller, 1997, Low-Activity Waste Feed Data Quality Objectives, WIT-98-010, Pacific Northwest National Laboratory, Richland, Washington. 


\section{DISTRIBUTION SHEET}

\begin{tabular}{|c|c|c|c|c|c|}
\hline \multirow[b]{2}{*}{ Distribution } & \multirow{2}{*}{\multicolumn{3}{|c|}{ Process Engine }} & \multicolumn{2}{|l|}{ Page 1 of 1} \\
\hline & & & & \multicolumn{2}{|c|}{ Date $\quad 10 / 08 / 98$} \\
\hline \multicolumn{4}{|l|}{ Project Title/Work Order } & \multicolumn{2}{|c|}{ EDT No. EDT-622483 } \\
\hline $\begin{array}{l}\text { HNF-3375, Rev. 0, "Tank } \\
\text { Analysis Plan" }\end{array}$ & 01 Push Mode & re Sampl & ig and & \multicolumn{2}{|l|}{ ECN No. N/A } \\
\hline \multicolumn{2}{|l|}{ Name } & $\begin{array}{c}\text { Text } \\
\text { With } \\
\text { A11 } \\
\text { Attach. }\end{array}$ & Text Only & $\begin{array}{l}\text { Attach./ } \\
\text { Appendix } \\
\text { Only }\end{array}$ & $\begin{array}{c}\text { EDT/ECN } \\
\text { Only }\end{array}$ \\
\hline
\end{tabular}

U. S. Department of Energy -

Richland Field Office

C. A. Babe?

W. Liou

J. A. Poppiti

$\begin{array}{ll}\text { S7-54 } & x \\ \text { S7-54 } & x \\ \text { S7-54 } & x\end{array}$

Duke Enqineering Services of Hanford

R. E. Bauer

S7-73 $\quad \mathrm{X}$

Lockheed Martin Hanford Corp.
D. C. Board
J. M. Conner
R. N. Dale
K. M. Hal1
W. J. Kennedy
J. S. Lee
J. G. Lewis
R. R. Thompson
S7-07
R2-11
S7-12
R2-12
$57-03$
S7-03
S7-01
$\mathrm{R} 2-12$
T.C.S.R.C.
R1-10

Lockheed Martin Services. Inc.

Central Fjles

B1-07 $\quad X$

Los Alamos Technical Associates

R. W. Lambie

57-04 $\quad X$

Numatec Hanford Corporation

W. I. Winters

T6-50 $\quad X$

Pacific Northwest National Laboratory

M. J. Truex

$K 2-10 \quad x$

Waste Management Federa] Services of Hanford, Inc.
R. Akita
R. A. Esch
R. K. Fulter
D. B. Hardy
K. L. Powel1
F. H. Steen

$\begin{array}{ll}\text { T6-20 } & X \\ \text { T6-12 } & X \\ \text { T6-50 } & X \\ \text { T6-12 } & X \\ \text { T6-12 } & X \\ \text { T6-12 } & X\end{array}$

DOE/RL READING ROOM

H2-53 X 